\title{
Ichraq Hammou,
}

University of Cadi Ayyad, Morocco

Sabrine Aboudou,

University of Cadi Ayyad, Morocco

Youssef Makloul,

Ph.D., University of Cadi Ayyad, Morocco

\section{SOCIAL MEDIA AND INTANGIBLE CULTURAL HERITAGE FOR DIGITAL MARKETING COMMUNICATION: CASE OF MARRAKECH CRAFTS}

\begin{abstract}
Morocco is endowed with an intangible cultural heritage of great interest at the global level, to which Moroccan craftsmanship, for which it is widely known internationally, makes a significant contribution. In today's, the notion of heritage is continuously expanding, experiencing an almost unlimited extension. The intangible heritage increasingly occupies a prominent place in the planning of several bodies, whose aim is to raise awareness among nations of the need to protect their cultural diversity and to help them to develop projects for the safeguarding and preservation of this category of heritage. The majority of marketing research has not addressed the issue of the relationship between social media communication and the promotion of intangible cultural heritage in the sense that there is an information deficit in addressing this issue. The concept of social media communication represents for professionals a lever of great importance since it has become indispensable to a good marketing strategy. It constitutes, in the context of research, a real tool for the promotion of intangible cultural heritage and the enhancement of territories. The main objective of this article is to explore the concept of intangible cultural heritage given the great importance it represents and its relationship with social media communication in the Moroccan context, especially in the promotion, transmission and even the safeguarding of this wealth. The study used a multidisciplinary exploratory in the fields of media communication and territorial marketing. Thus, the study focused on the two concepts: intangible cultural heritage and communication through social media, while analysing the nature of their interrelation in general and more specifically the relationship between communication through social media and the promotion of Marrakech handicrafts as part of Morocco's intangible cultural heritage. The results of this empirical study of an exploratory nature, conducted among 14 experts operating in the Moroccan handicrafts sector, demonstrated the existence of a strong relationship between the use of social media communication and the promotion of Moroccan intangible cultural heritage and more specifically the intangible cultural heritage of the city of Marrakech through the development and enhancement of its handicraft products.
\end{abstract}

Keywords: communication, intangible cultural heritage, Marrakech, Moroccan craftsmanship, social media.

Introduction. The proliferation of the use of new information technologies, including social media and the various innovative offerings, can offer their users a significant advantage when it comes to reducing or even eliminating the distance between culture and citizens. Indeed, the users of these social media will be able to acquire armour of information, more effectively, on different cultures (Piccialli and Chianese, 2017) in a more straightforward way and with the least effort.

The preservation of the intangible cultural heritage has become a big challenge for any country in the world that has the will to safeguard this wealth and to win the battle of cultural safeguarding (Chan, 2012).

Morocco, like other countries, shows a lot of interest in the preservation and promotion of the arts and crafts sector with strong cultural content, given its international renown in this sector, as well as the importance of the craftsmanship products for both Moroccan citizens and foreigners. The general idea of the paper is to understand the role of social media in the promotion of the intangible cultural heritage of Morocco, especially for handicrafts products from Marrakech. A literature review on the basic concepts of the problems will be presented, and then the presentation of the main results of the exploratory study, conducted through semi-structured interviews with several officials in the field of Moroccan crafts, and finish with a discussion of the results obtained.

Cite as: Hammou, I., Aboudou, S., \& Makloul, Y. (2020). Social Media and Intangible Cultural Heritage for Digital Marketing Communication: Case of Marrakech Crafts. Marketing and Management of Innovations, 1, 121127. http://doi.org/10.21272/mmi.2020.1-09 

Case of Marrakech Crafts

Literature Review. In recent years, the notion of intangible heritage has grown considerably with a proliferation of its uses ranging from economy to computing (Bortolotto, 2008). In most cases, the idea of intangible heritage is associated with a descriptive definition, referring to the concept of «intangible or immaterial cultural heritage». The latter is still limited to a more or less «expert» use and has got a normative value since the adoption of the Convention on Intangible Cultural Heritage at UNESCO. If the «national and material heritage» is identified with restricted territory, the intangible heritage of the communities goes beyond the strictly territorial boundaries to open up to the culture in movement (Bortolotto, 2008).

The concretization of the essence of cultural heritage was achieved after fifty years by Lenzerini (2011). It is, according to the author, a set of tangible and intangible environments impacting the life and work of people. Melon (2017), in his definition, attributed two characteristics to the intangible heritage: human and living. That is to say, its transfer from one community to another would necessarily imply its disappearance. The Convention for the Safeguarding of the Intangible Cultural Heritage had also emphasized this concept. It came to put in place several policies for the safeguarding of this heritage and not just its conservation. These policies aim to protect the holders of exceptional cultural knowledge, to enhance identity through the diversification of culture and to promote the transmission of this knowledge in the face of a rapidly growing Western modernization (Giguere, 2006, Isomura 2004: 42).

Intangible cultural heritage concerns, according to the text of the Convention (Article 2.2), five fields to which the concept of intangible cultural heritage could be appropriated: oral traditions and expressions, including language as a vector of intangible cultural heritage, the arts of the show, social practices, rituals and festive events, knowledge, and practices concerning nature and the universe, know-how related to traditional craftsmanship (Bortolotto, 2011).

Social media is a collection of digital applications, media, and platforms grouped around a common goal: facilitating collaborations, interactions, and content sharing (Kim and Ko, 2012, Richter and Koch, 2007). The dominance of Web 2.0 technologies and social media has made the use of this communication channel very widespread. Indeed, even businesses and government institutions make use of it and use it as a means of communication (Kim and Ko, 2012) and a marketing tool to promote assets (Timothy, 2018) directly.

The use of social media continues to grow as they provide users with a variety of sources of digital information created and shared online, making access to information more accessible and becoming more responsive to the user's information needs concerning products, services, brands and even problems (Chauhan and Pillai, 2013).

Referring to the theory of uses and gratifications as one of the most efficient approaches to understand the primary motivators for the purpose of social media, the user carefully chooses the media that best meets the user's needs (Gao and Feng, 2016, Katz et al., 1973). Based on several works (Katz et al., 1973, McQuail, 1984), Gao and Feng, (2016), elaborated a synthesis and a proposal of different types of social media gratification grouped into five sections: Seeking information; Entertainment; Social interaction; Self-expression; Print management.

The user of social media seeks, by connecting, to satisfy one of these gratuities, or even several at a time. Referring to current research, social media will be a tool for the communication of intangible cultural heritage to enable its transmission, safeguarding, and promotion.

The culture of a country is made up of several attributes such as norms and values, language, knowhow, preferences, music and thus, communication is its cornerstone (Khalid and Chowdhury, 2018). Indeed, according to Ohiagu and Okorie (2014), social media ensure a mission of transmission and transfer of intangible cultural heritage from one generation to another and even beyond territorial boundaries. In other words, social media users play a role as contributors and creators of online content to the extent that they like and share content from other users, which allows for the creation and exchange 

Marrakech Crafts

of content on the Internet (Dominick, 2012, Kaplan and Haenlein, 2010). Social media is a real means of communication and promotion of the immaterial cultural heritage of any country (Stuedahl, 2009) especially with the diversity of the different categories to which these media belong (Khalid and Chowdhury, 2018, Mills and Plangger, 2015): Blogs, Micro-Blogs, Video-Sharing Websites, Picture Sharing Websites, Social Networking Websites.

Indeed, the organizations that are responsible for the communication and promotion of intangible cultural heritage now have this diversity of social media that will enable them to widely disseminate information about culture and reduce or even eliminate the distances between these institutions and their target (Liew, 2014). Thus, social media can be qualified as a real means of a promotion offering several ways to improve, inform and interpret the heritage (Kalay, Kvan, and Affleck, 2007). From this logic, social media will provide a truly revolutionary approach to cultural heritage practice (Malpas, 2008).

Methodology and research methods. The field investigation approach focused on an «exploratory» data collection study. For the collection of information, the process of interviewing various officials within the Moroccan handicraft sector is used. The choice of the qualitative approach was made according to the nature of the data that was expected to collect to answer the research question (Baumard \& Ibert, 2003). Indeed, as previously stated, this research aims to know and understand the link between communication through social media and the promotion of intangible cultural heritage, specifically the Moroccan handicrafts sector. It was, therefore, necessary to choose the mode of collection through semi-structured interviews with different managers at different hierarchical levels.

The data that were aiming to collect was, therefore in the form of "words», which is why they are qualitative (Miles \& Huberman, 1984). Thus, the collected discursive and qualitative data allowed «rich and well-founded descriptions and explanations of processes anchored in a local context» (Miles \& Huberman, 2003).

The exploratory study was conducted with 14 experts in the craft sector. The choice of the interviewees was made based on their affiliation structures insofar as the promotion and preservation of the intangible cultural heritage is the primary mission of these organizations whose interest to have the opinion of several officials. All interviews lasted between 40 and 60 minutes. The questions asked were focused in the first place on the communication by social media. It was necessary to apprehend the promotion of the sector of the craftsmanship with strong cultural content in Morocco and finally, dwelling on the relation between the communication through social media and the development of the Moroccan crafts sector. Regarding the analysis of the results, a textual analysis by hand proceeded. The table below presents a summary of the different managers interviewed with their affiliate structures (Table 1).

Table 1. Interviewed Managers and Affiliation Structures

\begin{tabular}{|l|l|l|c|c|}
\hline \multicolumn{3}{|c|}{ Interviewees } & Date of the interview & Structure affiliation \\
\hline $\begin{array}{l}\text { Interviewee 1 } \\
\text { Interviewee 2 } \\
\text { Interviewee 3 } \\
\text { Interviewee 4 }\end{array}$ & $\begin{array}{l}\text { Interviewee 5 } \\
\text { Interviewee 6 }\end{array}$ & $\begin{array}{l}\text { Interviewee 8 } \\
\text { Interviewee 9 } \\
\text { Interviewee 10 }\end{array}$ & $\begin{array}{c}\text { September - October } \\
\text { / 2018 }\end{array}$ & $\begin{array}{c}\text { Ministry of Tourism, Air Crafts } \\
\text { and Social Economy - } \\
\text { Morocco }\end{array}$ \\
\hline Interviewee 1 & Interviewee 12 & $\begin{array}{c}\text { September - October } \\
\text { / 2018 }\end{array}$ & House of the artisan - Morocco \\
\hline Interviewee 13 Interviewee 14 & $\begin{array}{c}\text { September - October } \\
\text { / 2018 }\end{array}$ & $\begin{array}{c}\text { The Regional Directorate of the } \\
\text { Ministry of Tourism, Air Crafts } \\
\text { and SocialEconomy - } \\
\text { Marrakech }\end{array}$ \\
\hline
\end{tabular}

Sources: developed by the authors. 
I. Hammou, S. Aboudou, Y. Makloul. Social Media and Intangible Cultural Heritage for Digital Marketing Communication: Case of Marrakech Crafts

Results. The exploratory study of the relationship between social media communication and the promotion of handicraft products in the city of Marrakech revealed essential and significant results. Indeed, the semi-directive interviews that were conducted with several experts in the field of crafts in Morocco allowed a preliminary confirmation of the research problem. The results of the qualitative study concern the three principal axes of the research, namely: Communication through social media; The promotion of the crafts of the city of Marrakech; The relationship between social media communication and the development of the Marrakech handicrafts sector.

Along with the same lines of ideas, and in the same way of the structure of the interview guide, the discussions on communication via social media will be presented at first, then the talks concerning the promotion of Marrakesh's handicrafts, and finally those concerning the relationship between social media communication and the development of intangible cultural heritage - the case of Moroccan craftsmanship.

Regarding the first part of the research, the results of the exploratory study allowed to understand that communication by social media is of great importance, particularly in the promotion of products and even territories. The experts all focused on the benefits of these media primarily in terms of the reached target made up mainly of young people. It should also be added that this channel has an essential influence, especially when it comes to a first promotional message. Social networks are of enormous importance because they are the primary communication tool today. Interviewee 1 , «We first have the role of social networks in communication and promotion for both craft products and the promotion of the city». Interviewee 2, Some experts have also underlined the inexpensive cost of communication via social media «First of all because social networks are an instant, inexpensive means in comparison with promotional campaigns on TV or Radio». Interviewee 12,

According to these experts, it is an effective means of communication in that it makes it possible to reach a significant target. Interviewee 11 suggested that «The use of social media makes it possible to reach an exciting public quantitatively and qualitatively, quantitative justified by the mass and qualitative by the target of connected young people». The brand also constitutes, according to the experts, a better tool for promoting a given product, to specify that it may be a product of the craft industry or even of its country of origin in the sense that the territory is also a product requiring communication and promotional efforts to increase its attractiveness and brand image «... currently, a product that has no brand, is a product that does not exist on the market ...» Interviewee 4.

According to the majority of interviewees, Facebook is the largest and most influential social network in the sense that it has the most significant impact on Moroccan crafts. Indeed, according to experts, this channel is qualified by a platform for the marketing of essential craft products, while pointing out that consumers of these products are subdivided into two types: foreign consumers and local consumers.

The quality of the craft products is the first attribute affecting the consumer's purchase decision and comes first before the price. According to experts, a study of consumer behaviour concerning Moroccan handicraft products has shown that consumers pay a lot of attention to the quality of the product more than its price, especially when it comes to products whose composition could harm their health (such as leather used in slippers, handbags, ...). Some believe that quality is the first constraint to which the product of Moroccan craftsmanship is confronted to the extent that it becomes difficult to ensure the same level of quality among all craftsmen. According to Fort et al., (2006) the poor quality of a given product, and the consequent disappointment of the consumer can have disastrous consequences for the image of the product, products, or even for the image of the sector itself.

The results of the second axis of the interview guide reflect the importance of the city of Marrakech as a city known for its craftsmanship. Indeed, all the interviewees affirmed the relevance of the choice of the city of Marrakech for the framework of the study. It constitutes a leader in the field of the crafts and represents the essential site of the craft in Morocco «The city of Marrakech occupies an important place in the national development process of the sector of Crafts and the programs financed by the department 

Marrakech Crafts

of the craft industry, it occupies the 2nd rank nationally in terms of turnover made by the craft industry», Interviewee 5.

According to the results of the exploratory study, the Marrakech handicrafts product is a crucial concept in the promotion of the intangible cultural heritage of Morocco insofar as the Marrakech handicrafts product reflects a history, cultural identity and know-how «A craft product is part of the cultural heritage of a territory or a country, so it reflects its cultural identity, its history» Interviewee 3 and add Interviewee7: «lt should be known that a craft product is a product with strong cultural content that reflects the image of Morocco and its cultural identity. Indeed, the authenticity and particularity of the craft product reflect the quality of the product, its richness revealing an ancestral tradition still alive». The city of Marrakech is very rich in know-how. Also, it is a city famous worldwide. This combination of know-how and fame makes Marrakech a particular city. The innovation of the craftsmen of Marrakesh makes products of the crafts of Marrakech exceptional products from the point of view Design.

For the third line of the research, the results of the exploratory study demonstrated the existence of a strong relationship between social media communication and the promotion of the intangible cultural heritage of a country. According to the experts of the field, a craft product embodies a set of specificities specific to the territory such as the cultural identity of the country, its history, its heritage, and its knowhow. The interviewees also stressed the importance of using social networks to promote this relationship, even among them who have described social media sites as the primary vector in this relationship.

The valorization of the Moroccan artisanal heritage reinforces the brand image of the city. Also, the products of the crafts participate in the construction of a right image of the territory of Marrakech in particular and that of Morocco in general. Social media is one of the best ways to communicate and promote this link «A craft product represents a country and identity. Hence the link is powerful between the two. Indeed, a flocked Marrakech product on social media is a product that has a responsibility because it is a flag bearer of the city whether it wants it or not» Interviewee8.

Social media is, therefore, a source of information and information sharing for most people, so connected people can make a significant contribution to the promotion of the intangible cultural heritage of a given territory through sharing information about History, know-how, cultural identity and other components of this territory (Chauhan et Pillai, 2013).

In summary, the qualitative exploratory study has allowed collecting significant results, and to contextualize the research problematic. Indeed, the results of the exploratory analysis have shown that the opinions of Moroccan craftsmen experts significantly match the theoretical contributions in the sense that it confirmed the existence of a strong relationship between communication by social media and the promotion of intangible cultural heritage, as well as the interest of using these media because it constitutes a real means of development offering several ways of improving, informing and interpreting heritage (Kalay, Kvan, and Affleck, 2007).

Referring to the theory of uses and gratuities (Katz, 1974) whose one of its aims is to explain the real function of social media as well as their true importance, the results of the exploratory study also emphasized the vital role of social media in communication in general and in the promotion of the Moroccan handicraft sector in particular.

Conclusions. By comparing the results obtained from the study with the contributions of the literature, there is a significant similarity between the contents. Indeed, in the literature review, several authors have highlighted the crucial role of social media in communication in general and in the promotion of intangible cultural heritage in particular. The experts also confirmed these comments during the conducted interviews. In analysing the results of the exploratory research, a strong interrelation between the promotion of Moroccan handicrafts and the use of social media as the primary vector in this relationship is founded. 
I. Hammou, S. Aboudou, Y. Makloul. Social Media and Intangible Cultural Heritage for Digital Marketing Communication: Case of Marrakech Crafts

The brand is also an exciting promotional and communication tool, including the need to make use of it to promote intangible cultural heritage. It should be pointed out that the concept of the brand may concern a craft product and be transposed even to the territory (Trueman, Klemm \& Giroud, 2004). The quality of the Moroccan handicraft product is also the first attribute to which the consumer is very interested and occupies a predominant place in the purchase decision. Indeed, according to experts, the quality of the craft product is much more important to consumers than the selling price.

Among the most relevant results of the study, the social network Facebook has the vital role in the promotion of the intangible cultural heritage insofar as it constitutes, according to the persons in charge of the structures, the medium which impacts most the activity of the organisms of Moroccan craftsmanship. It is also worth highlighting the importance of the city of Marrakech in Moroccan craftsmanship and the role of the product of the crafts of Marrakech in the transmission of history, cultural identity, and knowhow. Moroccan and promote the brand image of Morocco entirely. This relationship will be enhanced through social media.

Authors Contributions This study is the result of a collaboration between three authors: I. H., S. A. and Y. M. I. H. was responsible for the conceptualization of the research through the formulation of the overall research objectives and goals, as well as the development and design of the research methodology. Validation of the study was carried out by I. H., S. A., and Y.M. writing original draft preparation, I. H.; writing review and editing, I. H.; supervision, Y. M.

\section{References}

Ancrage en basse Andalousie, U (2006). Vues anthropologiques sur le patrimoine culturel immaterial. Anthropologie et Societes, 30(2), 107-127. [Google Scholar]

Baumard, P., \& Ibert, J. (2003). Methodes de recherche en Management, chapitre 9.

Bortolotto, C. (2011). Le trouble du patrimoine culturel immateriel. Terrain, 26, 21-42. [Google Scholar]

Bortolotto, C. (2008). Les enjeux de l'institution du patrimoine culturel immateriel. Compte rendu du seminaire organise au Lahic (2006-2008). Culture et Recherche, 116-117. [Google Scholar]

Chan, C. Y. (2012). Safeguarding intangible cultural heritage in Hong Kong: A lesson to learn from Cantonese opera. HKU Theses Online (HKUTO).

Dominick, J. (2012). Dynamics of Mass Communication: Media in Transition. McGraw-Hill Higher Education.

Fort, F., \& Fort, F. (2006). Alternatives marketing pour les produits de terroir. Revue francaise de gestion, (3), 145-159. [Google Scholar] [CrossRef]

Gao, Q., \& Feng, C. (2016). Branding with social media: User gratifications, usage patterns, and brand message content strategies. Computers in Human Behavior, 63, 868-890. [Google Scholar] [CrossRef]

Kalay, Y., Kvan, T., \& Affleck, J. (Eds.) (2007). New heritage: New media and cultural heritage. Routledge. [Google Scholar]

Kaplan, A. M., \& Haenlein, M. (2010). Users of the world, unite! The challenges and opportunities of Social Media. Business horizons, 53(1), 59-68. [Google Scholar] [CrossRef]

Katz, E., Blumler, J. G., \& Gurevitch, M. (1973). Uses and gratifications research. The public opinion quarterly, 37(4), 509523. [Google Scholar]

Khalid, M. S., \& Chowdhury, M. S. A. (2018). Representation of intangible cultural heritage of Bangladesh through social media. Anatolia, 29(2), 194-203. [Google Scholar] [CrossRef]

Kim, A. J., \& Ko, E. (2012). Do social media marketing activities enhance customer equity? An empirical study of luxury fashion brand. Journal of Business Research, 65(10), 1480-1486. [Google Scholar] [CrossRef]

Lenzerini, F. (2011). Intangible cultural heritage: The living culture of peoples. European Journal of International Law, 22(1), 101-120. [Google Scholar] [CrossRef]

Liew, C.L. (2014). Participatory Cultural Heritage: A Tale of Two Institutions' Use of Social Media. D-Lib Magazine, 20(3), 1. [Google Scholar] [CrossRef]

Malpas, J. (2008). New media, cultural heritage and the sense of place: Mapping the conceptual ground. International Journal of heritage studies, 14(3), 197-209. [Google Scholar] [CrossRef]

McQuail, D. (1984). With the benefit of hindsight: Reflections on uses and gratifications research. Critical Studies in Media Communication, 1(2), 177-193. [Google Scholar] [CrossRef]

Melon, M. E. (2017). Le patrimoine culturel immateriel a l'ere de sa reproductibilite technique. Fonction des archives photographiques et cinematographiques. Patrimoine culturel immateriel, 97-115. [Google Scholar] 
I. Hammou, S. Aboudou, Y. Makloul. Social Media and Intangible Cultural Heritage Marketing Communication: Case of Marrakech Crafts

Miles, M. B., \& Huberman, A. M. (2003). Analyse des donnees qualitatives. De Boeck Superieur. [Google Scholar]

Mills, A. J., \& Plangger, K. (2015). Social media strategy for online service brands. The Service Industries Journal, 35(10), 521 536. [Google Scholar] [CrossRef]

Ohiagu, O. P., \& Okorie, V. O. (2014). Social media: Shaping and transmitting popular culture. Covenant Journal of Communication, 2(1). [Google Scholar]

Isomura, H. (2004). Le Japon et le patrimoine immateriel, Jean Duvignaud et Javier Perez de Cuellar (sous la dir. de), dans Le patrimoine culturel immaterial: Les enjeux, les problematiques, les pratiques, Paris, Maison des cultures du monde

Piccialli, F., \& Chianese, A. (2017). Cultural heritage and new technologies: Trends and challenges. [Google Scholar] [CrossRef] Richter A., Koch M. (2007) Social software: Status quo und Zukunft (pp. 1-49). Fak. Für Informatik, Univ. der Bundeswehr München.

Saji, K. B., Chauhan, K., \& Pillai, A. (2013). Role of content strategy in social media brand communities: a case of higher Education Institutes in India. Journal of Product \& Brand Management. [Google Scholar] [CrossRef

Stuedahl, D. (2009). Digital cultural heritage engagement: A new research field for ethnology. Ethnologia scandinavica, 39, 6781. [Google Scholar]

Timothy, D. J. (2018). Making sense of heritage tourism: Research trends in a maturing field of study. Tourism management perspectives, 25, 177-180. [Google Scholar] [CrossRef]

Trueman, M., Klemm, M., \& Giroud, A. (2004). Can a city communicate? Bradford as a corporate brand. Corporate communications: an international journal. [Google Scholar] [CrossRef]

Іхрак Хамму, Університет Каді Айяд (Марокко);

Сабрін Абуду, Університет Каді Айяд (Марокко);

Юсеф Маклоуль, Ph.D., Університет Каді Айяд (Марокко).

Соціальні мережі та нематеріальна культурна спадщина у цифровому маркетингу: на прикладі крафтового виробництва в Марракеш

У статті проаналізовано культурну спадщину Марокко та визначено про зростання ії популярності на світовому ринку, зокрема, за рахунок крафтового виробництва. Авторами наголошено, що роль нематеріальної культурної спадщини у Марракеш неухильно зростає. Результати аналізу наукової літератури засвідчили, що більшість маркетингових досліджень не враховують взаємозв'язок між цифрровими комунікаціями через соціальні мережі та просуванням нематеріальної культурної спадщини країни, що, у свою чергу, породжує інформаційну асиметрію та обмеженість. У статті доведено, що сучасний розвиток технологій та суспільства обумовлюе необхідність застосування інструментів цифррового маркетингу при формуванні стратегії промоції культурної спадщини країни. Авторами проаналізовано та систематизовано підходи до визначення сутності поняття нематеріальної культурної спадщини Марокко. У статті висунуто та емпірично підтверджено гіпотезу про наявність статистично значущого взаємозв'язку між нематеріальною культурною спадщиною та цифровими комунікаціями, а саме використанням соціальних мереж. Методологію дослідження засновано на міждисциплінарному аналізі наукової літератури та використанні статистичного аналізу. Авторами проаналізовано ефеективність просування нематеріальної культурної спадщини через соціальні мережі, а також ефективність промоції крафтового виробництва Марракеш в соціальних мережах. Вихідні панельні дані для дослідження згенеровано на основі результатів опитування 14 працівників міністерств та департаментів, що відповідають за розвиток туризму, крафтового виробництва та збереження культурної спадщини в Марокко. При цьому отримані результати свідчать про наявність статистично значущого взаємозв'язку між застосуванням комунікацій у соціальних мережах та ефективністю просування нематеріальної культурноі спадщини Марокко, зокрема, Марракешу, на основі популяризації та підвищенні якості продуктів крафтового виробництва. Авторами запропоновано посилити промоцію крафтового виробництва, як складової культурної спадщини Марокко через соціальні мережі. мережі.

Ключові слова: комунікації, нематеріальна культурна спадщина, Марракеш, Марокко, крафтова робота, соціальні

Manuscript received:

(C) The author(s) 2020. This article is published with open access at Sumy State University. 